\title{
Study on the Change of Financial Management Operation and the Corresponding Measures in the View of ERP
}

\author{
Meihua Xu \\ Liaoning Jianzhu Vocational College, Liaoyang, Liaoning, 111000
}

\begin{abstract}
The development of modern information technology, as well as information technology and accounting work integration, making financial accounting cost accounting has become relatively easy. Whether in China or other countries in the world, the use of ERP for internal and external resources to fully integrate the management model has aroused a new thinking on management thinking and management technology, more and more attention to the production enterprises. The use of ERP in financial management has always been the focus of enterprises. As the external environment and internal management model of the rate of change is accelerating, the financial management functions put forward new requirements. With the use of ERP in enterprise financial management, not only makes the scope of traditional enterprise financial management has been widened, but also to create a competitive advantage and the realization of enterprise value goals. This paper first describes the definition of ERP, and then studies the necessity of using ERP in financial management and the concrete application of ERP in financial management. Finally, it analyzes the difficulties and countermeasures of implementing ERP in Chinese enterprises.
\end{abstract}

Keywords: ERP system, Finance Management, Enterprise Development

\section{Introduction}

ERP is the abbreviation for Enterprise Resource Planning, translated into Chinese is the enterprise resource planning. The so-called enterprise resource planning system is the material resources, financial resources and information resources in 
one set, mainly for the manufacturing industry, enterprise information management system. Enterprise Resource Planning was first proposed in the 1990s by Gartner Group. ERP has very powerful system function and flexible application environment and real-time control ability. It is the most common and most used form in enterprise management information system at present. The significance of ERP is to optimize the management of resources as the starting point, the integration of external resources and internal resources, to achieve maximum business efficiency. The enterprise can realize the automatic management of enterprise funds, personnel, information and goods by using ERP. It has many commercial functions such as financial management, supply chain management, project management, human resource management and marketing. Enterprise resource planning in the enterprise computer to achieve enterprise management information and automation, improve business efficiency, has a very important practical significance. With the continuous development of ERP, which includes MRP and MRPII two aspects, but today's ERP concept has almost become synonymous with enterprise information.

\section{The role of ERP in enterprise financial management}

ERP is the enterprise resource planning management. Enterprise resource management includes procurement, production, sales, inventory, cost, financial, human resources and many other aspects. ERP is the integration of all resources within the enterprise and planning, so as to achieve the best combination of resources, for the purpose of the highest profits. ERP system will be the production management, supply chain and logistics, sales and customer service, financial management, human resources management of these five modules of effective integration of resources, a core part of enterprise management. The financial management module as a core part of ERP and contact other management links, in the enterprise information management has played a key role. The production and operation management is facing the problem of cost management, sales can not be separated from the accounts receivable management, supply chain, logistics and capital flows are closely related. At present, many companies have implemented or prepared to implement ERP systems are very concerned about as the core part of the financial management functions.

Based on the ERP environment of enterprise financial management system, which is the enterprise managers to manage the theoretical basis and means, and then determine the development of enterprises and objectives. As the external environment of modern enterprises is constantly changing, the enterprises have brought great pressure, but at the same time to the enterprise have brought new challenges and opportunities. In addition, the development of modern information technology to speed up the development process of the world, the world's development is the ultimate trend of economic globalization, enterprises in addition to facing competition in domestic enterprises, but also face international competition; The advent of the era of knowledge economy has greatly shortened 
the life cycle of enterprise products, enterprises need to fundamentally implement the strategic management to adapt to customer-oriented, competitive and rapid changes characterized by the external environment. ERP financial strategy management system is a kind of new management form which can develop in the future and can adapt to the environment. It has become a distinctive feature of modern enterprise, which helps enterprise managers to meet the challenges and opportunities faced by enterprises. .

\section{The change of financial management operation and management}

Whether in the manual accounting or computerized accounting financial management mode, financial management information must wait until the business process is completed, the relevant documents handed over to the financial sector, only by the financial sector to carry out the settlement of the corresponding business results and effectiveness evaluation. In this regard, the conclusions and effects of financial management are lagging behind, and often take the "after the remedy" approach. The ERP system to achieve the enterprise financial management module and other business modules in real-time integration, financial management can be effectively based on real-time accurate information to carry out. Because of the flattening of the information and management structure, the financial management has achieved the premanagement, forecasting and analyzing the potential risks in the business process of the enterprise, which plays a vital role in preventing the tax risk.

ERP system to long-term development goals, closely integrated with the production and operation of business processes, modular structure covering all aspects of production and operation management. ERP system mostly adopts C / (S client / server) or B / (S browser / server) structure, the server as the data warehouse carrier, realizing the whole supply chain information, production, supply and sales. The typical ERP system generally includes the basic modules such as system management, production management, sales management, purchasing management, financial accounting, management accounting, human resources management, office automation, project management, information inquiry, and financial management module as its core module, Through the data interface and other modules of mutual integration of information, so as to achieve a high degree of integration of enterprise financial management information. For example, the money management module to achieve the internal operation of the integrated management of funds, timely feedback on the operation of funds within the enterprise information is conducive to the allocation of funds within the enterprise to achieve capital utilization and production capacity maximization.

Traditional financial management thinking model is based on profit-oriented organizations launched, often easy to ignore the existence of non-profit organizations. The ERP system through the integration of SRM (supplier relationship management) and CRM (customer relationship management), 
breaking the traditional computerized accounting philosophy, information integration based on supply chain management and e-commerce based on the suppliers, customers and Partner information collection and integration. By combing business processes, all organizational behavior can be replicated in the supply chain model, so that ERP financial management not only for profit organizations, but also for non-profit organizations. Therefore, ERP standardization management process can be customized development by the user into a different organization specific management model.

At present, along with the rapid development of electronic commerce, the rapid change of data information for enterprise management and real-time feedback put forward higher requirements. At the same time, the ERP system keeps up with the demand of the times. Through the integration of SCM (supply chain management) and e-business management concepts, it helps enterprises to create a supply chain network that accords with their own operating characteristics, and integrates SRM concepts and CRM concepts into SCM concepts., The company's customers and suppliers to form a comprehensive information network system, with seamless information to build based on the supply chain system and e-commerce collaborative management model to achieve business data and business synchronization of all-round update, the formation of corporate capital flow, Information flow consistent to support enterprises to improve work efficiency.

\section{The solution to enterprise financial management}

First, a deep understanding of the financial management perspective ERP perspective of the new operation and maintenance, not just look at one of the financial module, but a deep understanding of financial management under ERP system contains advanced management concepts and their effects. The second is to further extend the use of data, combined with the customizable ERP reporting system can be added to the original audit report on the basis of the development of corporate tax returns in order to achieve the overall business process and external regulatory processes closed-loop management. The third is to strengthen the analysis of financial personnel to predict the theoretical capacity of training lectures, ERP system to achieve mass data storage and integration. According to business processes will be a large number of accounting by the computer automatically, effectively guarantee the accuracy of accounting information, complete financial personnel from the arduous accounting to liberate them to improve their ability to analyze and forecast. The fourth is to strengthen the financial management of enterprise costs, indirect costs and multinational group cost-sharing of the refinement of management. Financial management brought from the new ERP thinking is easy to see that cost control will be the key to success in the market competition. Therefore, enterprises need to further refine the cost management, in the appropriate circumstances to consider the introduction of $\mathrm{ABC}$ cost method (activity-based costing), to strengthen cost 
management and control, to achieve the operation and management operation and management of the profit maximization.

ERP project implementation is a system of management projects, its implementation involves a wide range, including business process reengineering, management model changes in all aspects of the enterprise. As the ERP implementation process will damage the interests of some people in the specific implementation process will be a certain degree of resistance, which requires the strong support of senior leadership to overcome the difficulties to ensure the smooth implementation of ERP. For the middle managers, the main task is to develop corporate objectives and the implementation of corporate local management policies; and for the grass-roots level, to actively participate in the work, to understand and master how to improve the daily decision-making ERP system accuracy, And how the ERP implementation process in line with other departments, and then to adjust their work and work content for the successful implementation of ERP to contribute.

The active participation of management personnel is the prerequisite and basis for ensuring the initial success of ERP implementation. However, with the development of the enterprise, the application of ERP system will become more and more extensive. Therefore, in order to meet this demand, it is necessary for the majority of managers to conduct more in-depth training, and continuously improve their application level for the implementation of ERP systems to provide a strong support.

\section{Conclusion}

All in all, ERP system reflects the modern management thinking and management model, the effective integration of external resources and internal resources, the implementation process is the process of concept and system of reform. To give full play to the real role of ERP system, bear the brunt of learning and to master the advanced management ideas, and only within the enterprise fully understand the ERP management thinking in order to work through interdepartmental collaboration between the various departments and do a good job ERP implementation. ERP system using modern management mode makes enterprise management and operation mode has been greatly improved, directly improve the market competitiveness of enterprises. The essence of enterprise management is to achieve the high efficiency of financial management, ERP financial management system just for the enterprise's financial sector provides a good platform for financial personnel in the ERP system implementation process should be bold, bold attempt to promote the ERP financial Management system better and faster to move forward. 


\section{Acknowledgement}

Topic Title: Exploration and Practice of Specialty Construction of Financial Management Major

Project Number: JZXYKT-201520

\section{References}

[1] Li Qiang. The finer financial management of export enterprises. Management, 31(2), pp. 18-21, 2016

[2] Fang Yuping. Analysis and improvement of enterprise financial management . Modern Economic Information, 21(3), pp. 39-45, 2016.

[3] Xu Zhouxia. Accounting information on the impact of corporate financial management and countermeasures . Accounting study, 22(2), pp. 58-65, 2016.

[4] Zhang Zhitong. Accounting information on the impact of enterprise financial management and countermeasures. Modern economic information, 20(1), pp. 7879, 2015.

[5] Zeng Bengpeng. The effect and countermeasure of centralized accounting of large enterprises on financial management .Global Business, 23(2), pp. 11-12, 2015. 